\title{
THE USE OF BLUETOOTH STANDARD FOR COMMUNICATION BETWEEN VEHICLES UNDER TRAFFIC
}

\section{WYKORZYSTANIE STANDARDU BLUETOOTH DO KOMUNIKACJI POMIĘDZY POJAZDAMI W WARUNKACH RUCHU}

\author{
Zbigniew Kasprzyk, Mariusz Rychlicki \\ Warsaw University of Technology, Department of Transport \\ Politechnika Warszawska, Wydział Transportu
}

\begin{abstract}
Bluetooth is a type of wireless communication used to transmit voice and data at high speeds using radio waves. It is a standard protocol for short-range radio communications between many different types of devices, including mobile phones, computers and other electronics [1]. The trend of integrating new services in vehicles increases rapidly and Bluetooth is one of the emerging communication technologies for realizing ad-hoc networks. The paper presents the possibility of using Bluetooth to build ad-hoc network suitable for the transmission of sound, in particular voice data using the modulation GSFK. We analyzed the features or problems that Bluetooth offers for transmitting audio data in an ad-hoc network. Some initial results of simulations and real-life tests give an impression of the performance and efficiency this standard for the transmission of voice data in an ad-hoc networks [2].
\end{abstract}

Keywords: bluetooth standard, communication between vehicles in traffic, shortrange wireless communication

Streszczenie: Bluetooth jest rodzajem taczności bezprzewodowej wykorzystywanej do transmisji głosu i danych z duża prędkościa za pomoca fal radiowych. Jest to standardowy protokót krótkiego zasięgu taczności radiowej pomiędzy wieloma różnymi typami urządzeń, $w$ tym telefonów komórkowych, komputerów $i$ innych urządzeń elektronicznych [1]. Tendencja integracji nowych ustug $w$ pojazdach gwaltownie wzrasta a technologia Bluetooth jest jedna z rozwijajacych sie technologii do realizacji sieci typu ad-hoc. W pracy zaprezentowano możliwości wykorzystania technologii Bluetooth do budowy sieci ad-hoc odpowiedniej do przesytania dźwięku, w szczególności danych głosowych $z$ wykorzystaniem modulacji GSFK. Przeanalizowano problemy i możliwości jakie oferuje Bluetooth do przesytania danych glosowych $w$ sieci ad-hoc. Wstepne wyniki symulacji $i$ analiza badań rzeczywistych daje wyobrażenie o wydajności i efektywności wykorzystania tego standardu do transmisji danych glosowych w sieci ad-hoc [2].

Stowa kluczowe: standard bluetooth, komunikacja między pojazdami w ruchu, transmisja danych na bliskie odległości 
The use of bluetooth standard for communication between vehicles under traffic Wykorzystanie standardu bluetooth do komunikacji pomiędzy pojazdami ...

\section{THE USE OF BLUETOOTH STANDARD FOR COMMUNICATION BETWEEN VEHICLES UNDER TRAFFIC}

\section{Introduction}

One of the possible applications of wireless data transmission is ensuring communication between vehicles under traffic, in particular, voice transmission over short distances. The Bluetooth system, due to its topology of the pikonet subnetwork, seems interesting in terms of the application for wireless voice transmission between drivers of vehicles under traffic. A typical network range is $10 \mathrm{~m}$ with the possibility of extending up to $100 \mathrm{~m}$ using modulation and GFSK GaussianFrequencyShiftKeying) with a BT coefficient of 0.5 and a bit rate of $1 \mathrm{Mb} / \mathrm{s}$. This paper presents a simulation test in a Matlab-Simulink environment, involving voice transmission with the use of two Bluetooth devices, which can be used for communication between vehicles under traffic.

\section{Voice transmission simulation between two Bluetooth devices for communication between two vehicles under traffic}

In order to simulate voice transmission between two Bluetooth receivers in a pikonet network, a model in the Matlab-Simulink environment was used for communication between vehicles under traffic [4]. The presented model enables simulating voice transmission in the duplex mode, between two Bluetooth devices located in vehicles in motion. The model supports 4 voice data package types, HV1, HV2, HV3 and SCORT and one data package type, DM1. The simulation parameter change block (fig. 1) has the possibility to configure simulation input data, such as: channel type, data package type and the number of time slots.

\begin{tabular}{l} 
Bi. Block Parameters: Model Parameters \\
Model Parameters (mask) \\
Configures both devices to specified system parameters. Takes \\
extra initialization time. EsNo is defined in the MATLAB workspace. \\
Default is 18dB. \\
Parameters \\
Channel type AWGN and $802.11 \mathrm{~b}$ \\
Packet_type HV1 \\
Initial Slot Pair for HV2 or HV3 182 \\
$\qquad$\begin{tabular}{|c|c|}
\hline OK \\
Cancel
\end{tabular} \\
\hline
\end{tabular}

Fig. 1 Block for changing the simulation parameters of voice transmission between two Bluetooth receivers in a pikonet network 
The model enables simulating the operation of a Bluetooth device in a pikonet consisting of devices of the master, slave types and a transmission channel. A group of Bluetooth devices operates over one physical channel forming a basic network structure of a pikonet type. Within this network, one of the simulated devices operates in a master mode, and the remaining ones in the slave mode. A master device in each pikonet, defines time slots with a length of $625 \mu \mathrm{s}$. The transmission of a master device starts with even slots, whereas the transmission of a slave device with odd slots. Traditional time-division multiplexing (TDM) is present, where a master device takes half of the slots and a slave device the remaining part. Frames may have the length of one, three or five time slots. The model takes into account CVSD speech coding and GFSK modulation, together with CRC error calculation for the DM1 package, HEC header error control), FEC (forward error correction) and interference during data transmission for the $802.11 \mathrm{~b}$ standard. The subsystem acting as a transmitted (fig. 2) in the simulation model consists of a block controller operating based on Bluetooth specification part B 7.6, FEC block forward error correction) based on Bluetooth specification part B 7, data frame block based on Bluetooth specification part B 6.1, 6.4 and 7.3 and a radio block based on Bluetooth specification part A 3.1.

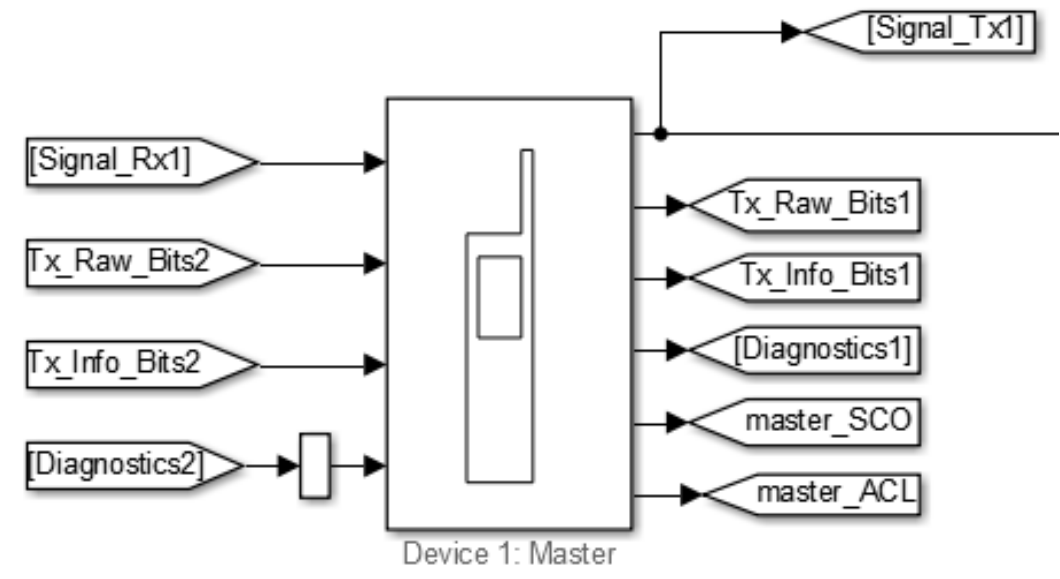

Fig. 2 Subsystem executing the master transmitter function of a Bluetooth network in a simulation model

The simulation model also contains a sub-system responsible for simulating the channel type for voice or data transmission in a Bluetooth network (fig. 3). This subsystem enables also taking into account the interference occurring during data transmission for the $802.11 \mathrm{~b}$ standard and the selection of additive interference modelling in a transmission channel using the AWGN (Additive White Gaussian Noise) channel, namely, with the Gaussian additive interference or simulating a direct full-duplex connection of Bluetooth devices in a set up channel. 
The use of bluetooth standard for communication between vehicles under traffic Wykorzystanie standardu bluetooth do komunikacji pomiędzy pojazdami ...
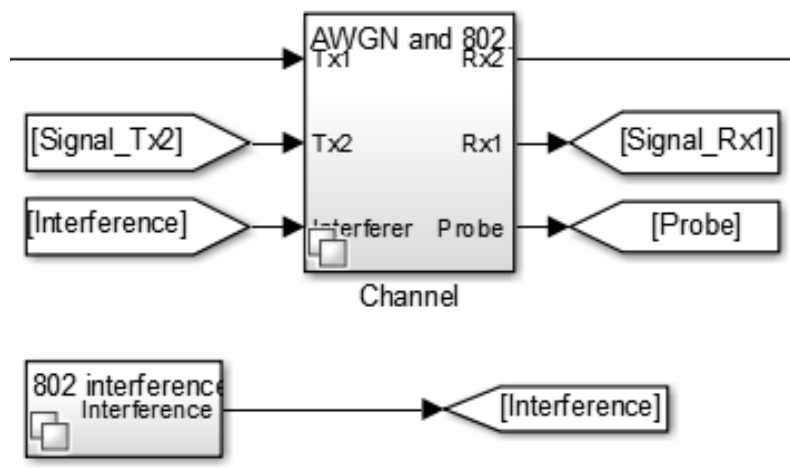

Fig. 3 Subsystem executing the possibility of selecting the type of a transmission channel simulation, together with the simulation of interference for the $802.11 \mathrm{~b}$ standard

Another subsystem in the model is a one executing the operational simulation of a voice transmission receiver in a Bluetooth network as a radio device operating in the slave mode (fig. 4).

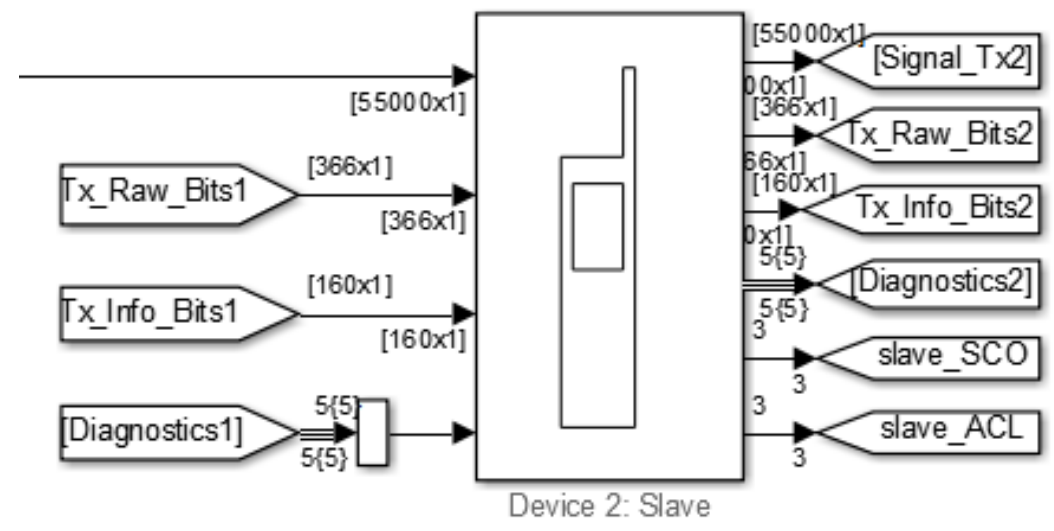

Fig. 4 Subsystem executing the function of a slave receiver of a Bluetooth network in a simulation model

The subystem consists of a block controller operating based on Bluetooth specification part B 7, radio block based on Bluetooth specification part A 4.1 and a block executing the separation of bits from the data frame, based on Bluetooth specification part B 7. The model also includes two input signals to subsystems, simulating two types of logical ACL Asynchronous Connection-Less) and SCO Synchronous Connection Oriented) channels for both a master, as well as slave devices. The first of the logical ACL channels is used in combination with package commutation, when data is available at irregular time intervals. The ACL logical channel does not give any guarantees that a frame will reach its target. Frames may be lost and require re-transmitting. 
A slave-type device may have only one ACL logical channel with a master device. A second logical channel is the SCO and is used for real-time transmission, usually, voice transmission. Frames transmitted with the SCO cannot be re-transmitted. FEC error correction is used in order to ensure data transmission reliability. A slave-type device may use a maximum of three SCO channels when transmitting to a master. Modelled signals between two master and slave devices enables simulation of data exchange in a pikonet. A Tx_Raw_Bits1 simulates operation when a master device randomly generates information data, determines CRS and FEC, sends them according to a format defined by Bluetooth (similarly to the case of Tx_Raw_Bits2 for a slave-type device). A Signal_Tx1 signal simulates operation when a master device receives Tx_Raw_Bits1 and modulates as per the Bluetooth standard. A Signal_Tx1 signal is transmitted by a channel (similar to a Signal_Tx2 signal for slave-type devices). A Signal_Rx1 signal simulates operation when a primary signal is received under AWGN additive distortion and interference during data transmission for an $802.11 \mathrm{~b}$ standard. A Signal_Rx1 signal is sent to a master-type device for demodulation and detection (similar to Signal_Rx2 for a slave-type device). A Tx_Info_Bits1 signal simulates operation when information data are generated by a master device with a CRC data field header but without FEC error correction. Tx_Info_Bits1 is used for checking the BER Bit Error Rate) in an SCO logical channel on the slave side (similar to Tx_Info_Bits2 for a mastertype device). A Diagnostics2 signal sends a set of information on the frames and packages for BER control in an ACL logical channel on the master side (similar to a Diagnostics2 signal for slave-type devices). A master_SCO signal simulates the transmission of BER information over an SCO logical channel from a master device (similar to slave_SCO for slave-type devices). A master_ACL signal simulates the transmission of BER information over an ACL logical channel from a master device (similar to slave_ACL for slave-type devices). The Interference signal simulates an interference signals generated from an $802.11 \mathrm{~b}$ channel.

In order to simulate voice transmission between two Bluetooth devices, the simulation model was configured so that the audio layer sound packages were transmitted over an SCO logical channel. In the course of the simulation, audio packages are sent within defined time slots and transmitted in pairs in the master to slave direction and vice versa. Three types of audio packages were simulated:

- HV1 package transmitting audio data coded with the use of FEC 1/3, occupying an entire physical channel in a pikonet,

- HV2 package transmitting audio data coded with the use of FEC 2/3, transmitted every 4 time slots,

- HV3 package transmitting non-coded audio data, transmitted every 6 time slots. 
The use of bluetooth standard for communication between vehicles under traffic Wykorzystanie standardu bluetooth do komunikacji pomiędzy pojazdami ...

The simulation model contains blocks counting transmission parameters in a Bluetooth network (fig. 5). The data throughput and BER bit error rate is determined there for both the ACL and SCO logical channels, in master and slave devices.

The blocks determine three types of BER errors:

- Raw BER - inconsistencies between bits in a transmitted and received signal,

- Residual BER - the probability that a given bit is faulty and will not be properly detected,

- FER - determines the ration of the number of damaged data frames to the total frame number caused by noise and distortion, and interference.

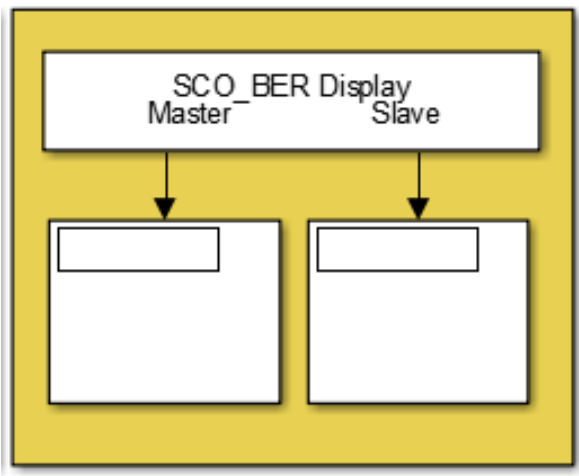

SCO BER Display

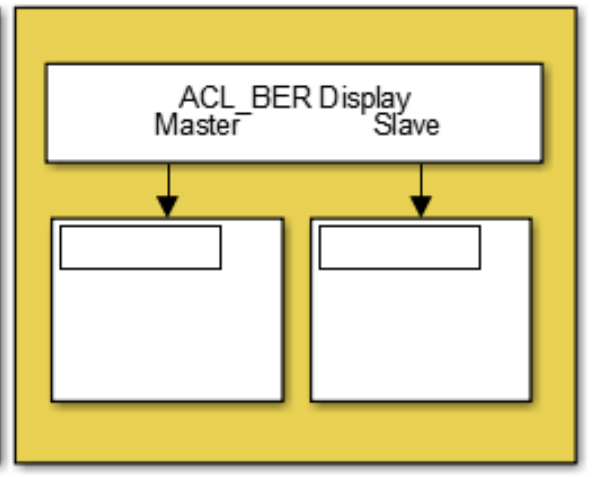

ACL BER Display

Fig. 5 Blocks counting transmission parameters in a Bluetooth network for ACL and SCO logical channels

Running the simulation generates a timing diagram in figure 6 , showing when a Bluetooth transmitter is operating. The graph in figure 7 presents a spectrum channel for each channel, showing the current Bluetooth transmission frequency. These two features are considered together in terms of a spectrogram in figure 8, so that it is easy to track the frequency jump in the time function.

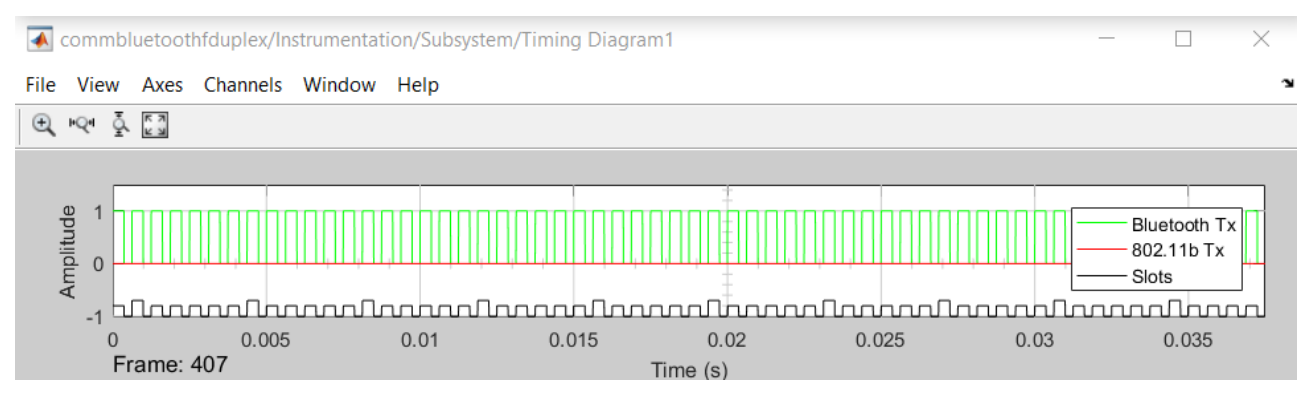

Fig. 6. Timing diagram of a Bluetooth transmitter 


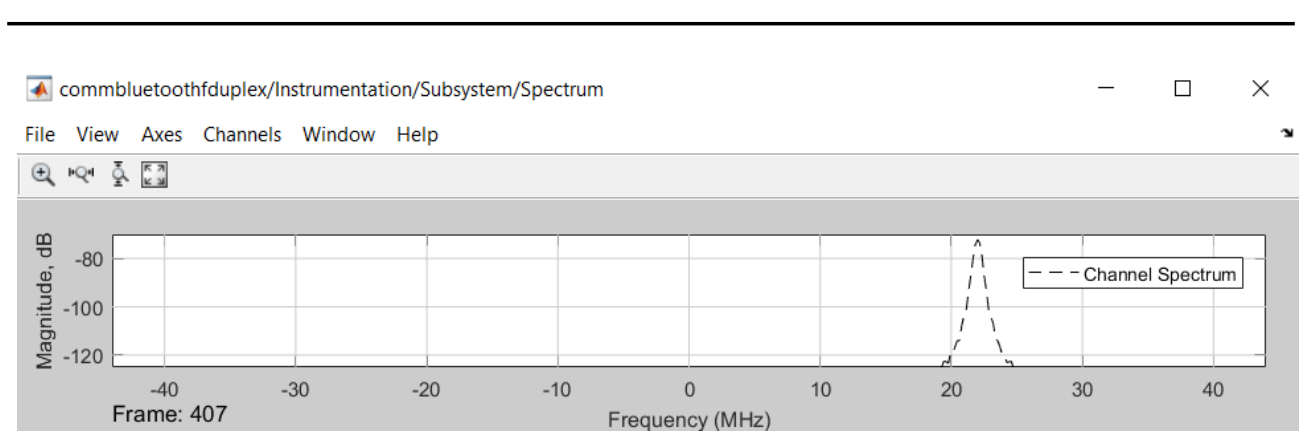

Fig. 7 Spectrum channel of a Bluetooth channel

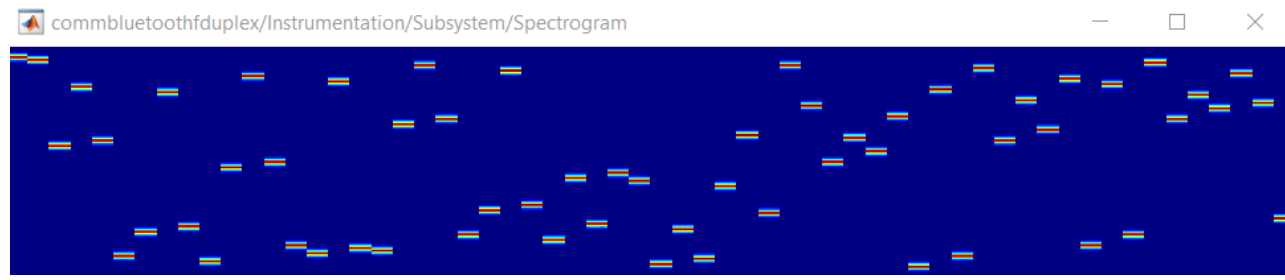

Fig. 8 Bluetooth transmission spectrogram

When the $802.11 \mathrm{~b}$ transmitter is activated, a Bluetooth transmitter timing diagram shown in figure 9 indicates overlapping of Bluetooth and 802.11b transmission. The spectrogram in figure 10 explicitly shows interaction of the transmission by two devices, resulting in a clash of data packages.

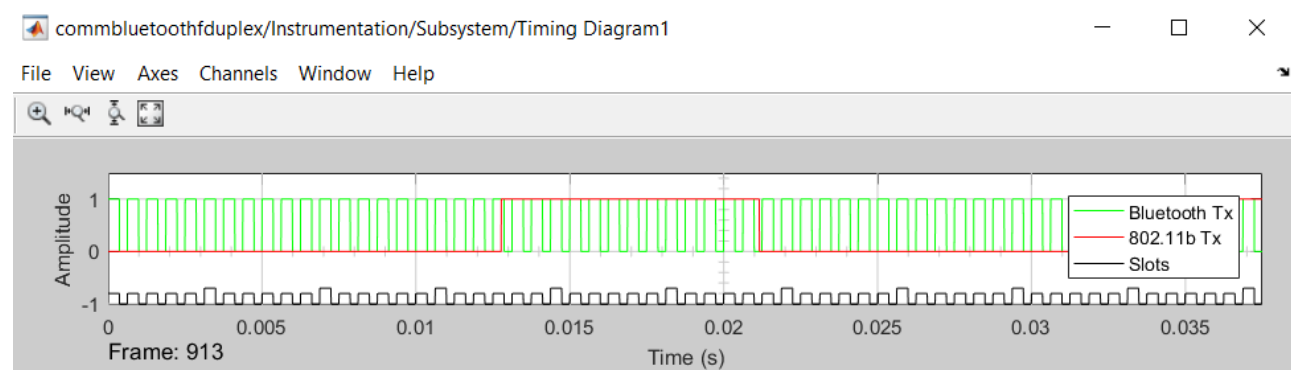

Fig. 9 Timing diagram of a Bluetooth transmitter with activated $802.11 \mathrm{~b}$ transmission

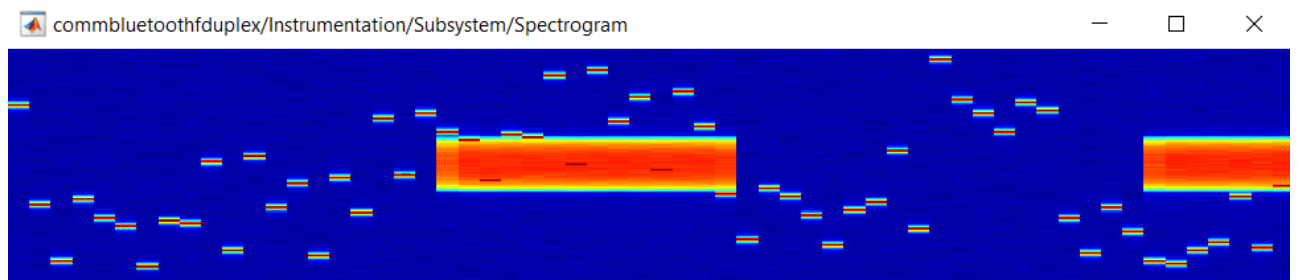

Fig. 10 Bluetooth transmission spectrogram with activated $802.11 \mathrm{~b}$ transmission 
The use of bluetooth standard for communication between vehicles under traffic Wykorzystanie standardu bluetooth do komunikacji pomiędzy pojazdami ...

The results of voice transmission simulation between two Bluetooth receivers for communication between vehicles in traffic conditions are shown in table 1.

Tab. 1 Simulation results of voice transmission in an SCO logical channel

\begin{tabular}{|l|l|l|l|c|c|c|c|c|}
\hline $\begin{array}{c}\text { Channel } \\
\text { type }\end{array}$ & $\begin{array}{c}\text { Package } \\
\text { type }\end{array}$ & $\begin{array}{c}\text { Number } \\
\text { of } \\
\text { frames }\end{array}$ & \multicolumn{2}{|c|}{ Raw BER } & \multicolumn{2}{c|}{ Residual BER } & \multicolumn{2}{c|}{ FER } \\
\hline $\begin{array}{l}\mid l \\
\text { Direct } \\
\text { connection }\end{array}$ & HV1 & 1000 & $1.859 \mathrm{e}+05$ & $1.863 \mathrm{e}+05$ & 0 & 0 & 0 & 0 \\
\hline $\begin{array}{l}\text { Direct } \\
\text { connection }\end{array}$ & HV2 & 1000 & $8.857 \mathrm{e}+04$ & $8.894 \mathrm{e}+04$ & 0 & 0 & 0 & 0 \\
\hline $\begin{array}{l}\text { Direct } \\
\text { connection }\end{array}$ & HV3 & 1000 & $6.222 \mathrm{e}+04$ & $6.222 \mathrm{e}+04$ & 0 & 0 & 0 & 0 \\
\hline AWGN & HV1 & 1000 & $1.859 \mathrm{e}+05$ & $1.863 \mathrm{e}+05$ & 0 & 0 & 0 & 0 \\
\hline AWGN & HV2 & 1000 & $9.370 \mathrm{e}+04$ & $9.370 \mathrm{e}+04$ & 0 & 0 & 0 & 0 \\
\hline AWGN & HV3 & 1000 & $6.185 \mathrm{e}+04$ & $6.185 \mathrm{e}+04$ & 0 & 0 & 0 & 0 \\
\hline $\begin{array}{l}\text { AWGN } \\
802.11 \mathrm{~b}\end{array}$ & HV1 & 1000 & $1.867 \mathrm{e}+05$ & $1.867 \mathrm{e}+05$ & 0.003118 & 0.001907 & 582 & 356 \\
\hline $\begin{array}{l}\text { AWGN } \\
802.11 \mathrm{~b}\end{array}$ & HV2 & 1000 & $9.333 \mathrm{e}+04$ & $9.333 \mathrm{e}+04$ & 0.003139 & 0.002325 & 293 & 217 \\
\hline $\begin{array}{l}\text { AWGN } \\
802.11 \mathrm{~b}\end{array}$ & HV3 & 1000 & $6.259 \mathrm{e}+04$ & $6.259 \mathrm{e}+04$ & 0.005928 & 0.003419 & 371 & 214 \\
\hline
\end{tabular}

\section{Summary and conclusions}

The conducted simulation of Bluetooth voice transmission over an SCO logical channel shows that together with increasing transmission time, which is associated with the number of transmitted and received frames, the possibility of interference between the $802.11 \mathrm{~b}$ and Bluetooth transmission increases. For the AWGN and 802.11 channels, in the case of interference and additive distortion, the largest number of damaged voice data frames and inconsistencies between the bits in the transmitted and received signals, with the same transmission time, occurs in the HV1 package transmitting audio data coded with FEC 1/3, occupying the entire physical channel. 


\section{Bibliography}

[1] http://www.bluetooth.com

[2] Marc Bechler, Jochen Schiller, Lars Wolf.: In-car communication using wireless technology, 8th World Congress on Intelligent Transport Systems, Sydney, Australia 2001-9-30 to 2001-10-4.

[3] F. Kargl, S. Ribhegge: Bluetooth-based ad-hoc networks for voice transmission, System Sciences, 2003. Proceedings of the 36th Annual Hawaii International Conference on 6-9 Jan. 2003

[4] https://www.mathworks.com/help/comm/examples/bluetooth-full-duplexvoice-and-data-transmission.html?requestedDomain=true

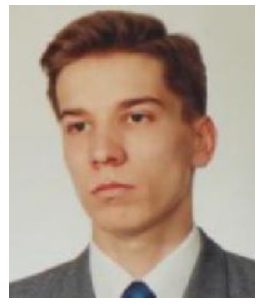

Zbigniew Kasprzyk, Ph.D., Assistant Professor, Department of Transport, Warsaw University of Technology. Research interests: modeling of toll systems, modeling of the functions of transport telematics equipment, analysis of operating systems, reliability analysis of data communication networks. Author of dozens of scientific-technical articles (Share 50\%).

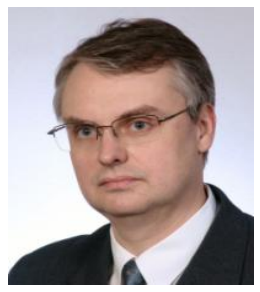

Mariusz Rychlicki, Ph.D., Assistant Professor, Department of Transport, Warsaw University of Technology. Research interests:modeling of telematics systems, analysis of localization monitoring and systems, reliability analysis of data communication networks. Author of dozens of scientific-technical articles (Share 50\%). 
The use of bluetooth standard for communication between vehicles under traffic Wykorzystanie standardu bluetooth do komunikacji pomiędzy pojazdami ...

\section{WYKORZYSTANIE STANDARDU BLUETOOTH DO KOMUNIKACJI POMIĘDZY POJAZDAMI W WARUNKACH RUCHU}

\section{Wstęp}

Jednym z możliwych zastosowań bezprzewodowej transmisji danych jest zapewnienie łączności pomiędzy pojazdami w ruchu, w szczególności transmisji głosowej na bliskie odległości. System Bluetooth ze względu na swoją topologię podsieci pikonet wydaje się interesujący $\mathrm{w}$ zastosowaniu do bezprzewodowej transmisji głosu pomiędzy kierowcami pojazdów w ruchu. Typowy zasięg sieci to $10 \mathrm{~m}$ przy możliwości zwiększenia do $100 \mathrm{~m}$ stosując modulację a GFSK (ang. Gaussian Frequency Shift Keying) ze współczynnikiem BT 0.5 i prędkością transmisji wynoszącą $1 \mathrm{Mb} / \mathrm{s}$. W niniejszej pracy przeprowadzono badanie symulacyjne, w środowisku Matlab-Simulink, transmisji głosu z wykorzystaniem dwóch urządzeń Bluetooth która może być wykorzystana do komunikacji pomiędzy pojazdami w warunkach ruchu.

\section{Symulacja transmisji głosu pomiędzy dwoma urządzeniami Bluetooth do komunikacji pomiędzy pojazdami w warunkach ruchu}

W celu przeprowadzenia symulacji transmisji głosu pomiędzy dwoma odbiornikami Bluetooth $\mathrm{w}$ sieci pikonet, do komunikacji pomiędzy pojazdami w ruchu, wykorzystano model w środowisku Matlab-Simulink [4]. Zaprezentowany model umożliwia przeprowadzenie symulacji transmisji głosu w trybie duplex pomiędzy dwoma urządzeniami Bluetooth umieszczonymi w pojazdach znajdujących się w ruchu. Model obsługuje 4 typy pakietów danych głosowych HV1, HV2, HV3 oraz SCORT i jeden rodzaj pakietu danych DM1. W bloku zmiany parametrów symulacji (rys. 1) jest możliwość dokonania konfiguracji danych wejściowych symulacji takich jak: typ kanału, typ pakietu danych oraz ilości slotów czasowych.

Model umożliwia symulację działania urządzeń Bluetooth w pikosieci składającej się z urządzeń typu master, slave oraz kanału transmisyjnego. Grupa urządzeń Bluetooth pracuje $\mathrm{w}$ jednym kanale fizycznym tworząc podstawową strukturę sieciową typu pikonet. W ramach tej sieci jedno z symulowanych urządzeń pracuje $\mathrm{w}$ trybie master, pozostałe urządzenie $\mathrm{w}$ trybie slave. Urządzenie typu master w każdej pikosieci definiuje sloty czasowe o długości $625 \mu$ s. Transmisja urządzenia typu master zaczyna się od slotów parzystych natomiast transmisja urządzenia typu slave od slotów nieparzystych. Występuje tradycyjna multipleksacja w dziedzinie czasu (TDM), gdzie urządzenie typu master zajmuje polowe slotów, a urządzenie typu slave pozostałą część. Ramki mogą mieć długość jednego, trzech lub pięciu slotów czasowych. 
Model uwzględnia kodowanie mowy typu CVSD oraz modulację GFSK wraz z kalkulacją błędów CRC dla pakietu DM1, HEC (ang. header error control) , FEC (ang. forward error correction) oraz interferencje przy transmisji danych dla standardu 802.11b.

Model Parameters (mask)
Configures both devices to specified system parameters. Takes
extra initialization time. EsNo is defined in the MATLAB workspace.
Default is 18dB.
Parameters
Channel type AWGN and $802.11 \mathrm{~b}$
Packet_type HV1
Initial Slot Pair for HV2 or HV3 1\&2
\begin{tabular}{|c|} 
OK \\
Cancel
\end{tabular}

Rys. 1 Blok zmiany parametrów symulacji transmisji glosu pomiędzy dwoma odbiornikami Bluetooth w sieci pikonet

Podsystem realizujący funkcję nadajnika (rys. 2) w modelu symulacyjnym składa się z kontrolera bloku działającego w oparciu o specyfikację Bluetooth część B 7.6, bloku FEC (ang. forward error correction) w oparciu o specyfikację Bluetooth część B 7, blok ramki danych w oparciu o specyfikację Bluetooth część B 6.1, 6.4 i 7.3 oraz blok radiowy w oparciu o specyfikację Bluetooth część A 3.1.

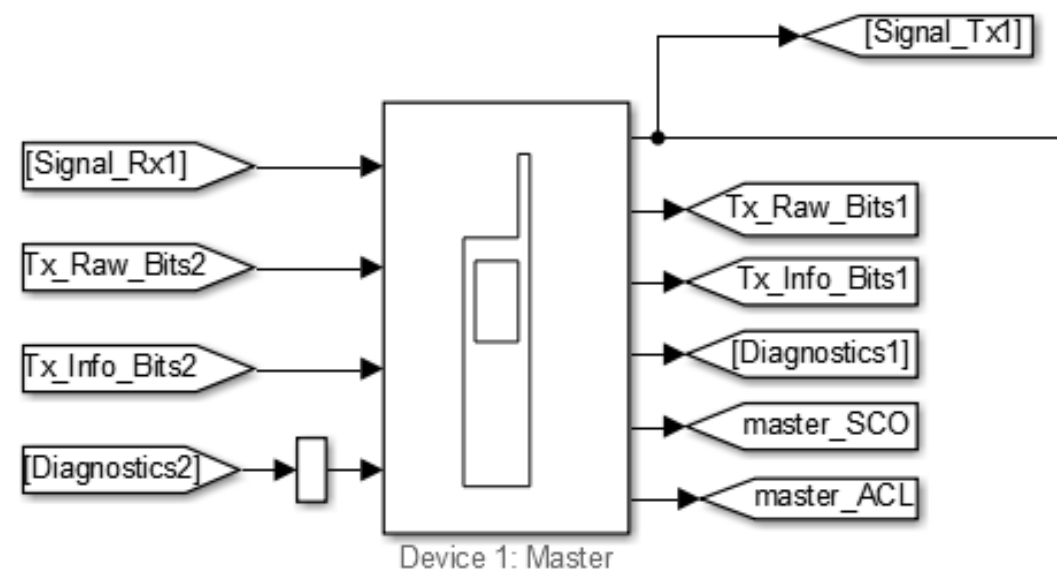

Rys. 2 Podsystem realizujacy funkcję nadajnika typu master sieci Bluetooth w modelu symulacyjnym 
The use of bluetooth standard for communication between vehicles under traffic Wykorzystanie standardu bluetooth do komunikacji pomiędzy pojazdami ...

W modelu symulacyjnym znajduje się również podsystem odpowiadający za symulacje typu kanału do transmisji głosu lub danych w sieci Bluetooth (rys. 3). Podsystem ten umożliwia również uwzględnienie w symulacji interferencji zachodzących przy transmisji danych dla standardu $802.11 \mathrm{~b}$ oraz wybór modelowania w kanale transmisyjnym zakłóceń addytywnych stosując kanał AWGN (ang. Additive White Gaussian Noise) czyli z gaussowskim zakłóceniem addytywnym, lub też symulowanie bezpośredniego połączenia w pełnym dupleksie urządzeń Bluetooth w zestawionym kanale.
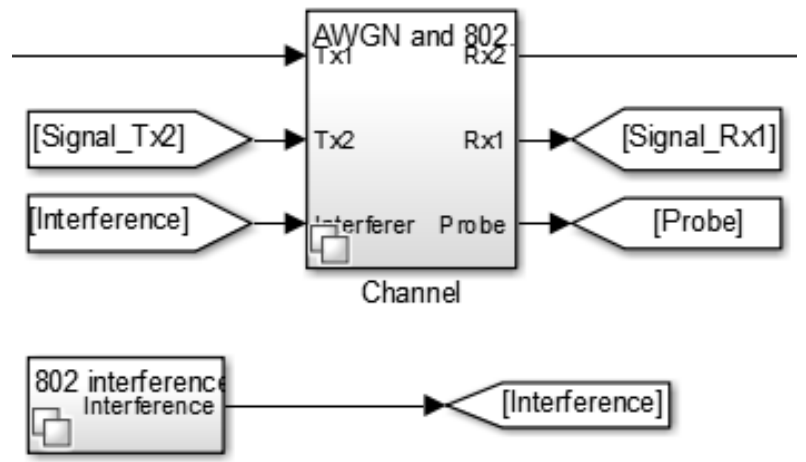

Rys. 3 Podsystem realizujacy możliwość wyboru rodzaju symulacji kanatu transmisyjnego wraz z symulacja interferencji dla standardu $802.11 \mathrm{~b}$

Kolejnym podsystemem w modelu jest podsystem realizujący symulację działania odbiornika transmisji głosu w sieci Bluetooth jako urządzenie radiowe pracujące w trybie slave (rys. 4).

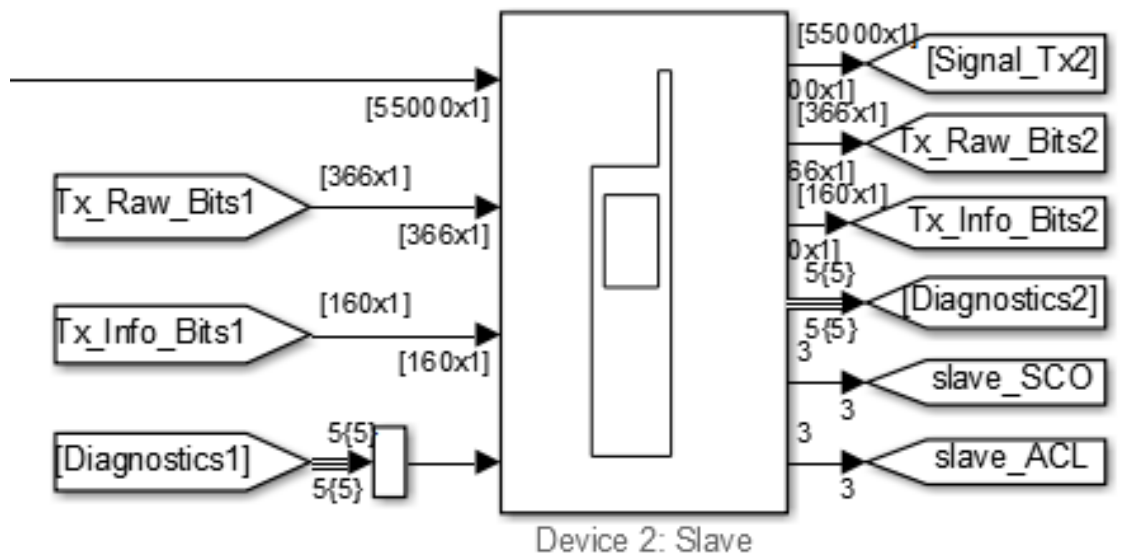

Rys. 4 Podsystem realizujacy funkcje odbiornika typu slave sieci Bluetooth w modelu symulacyjnym 
Podsystem ten składa się z kontrolera bloku działającego w oparciu o specyfikację Bluetooth część B 7, blok radiowy w oparciu o specyfikację Bluetooth część A 4.1 oraz blok realizujący separację bitów z ramki danych $\mathrm{w}$ oparciu o specyfikację Bluetooth część B 7. W modelu znajdują się również sygnały wejściowe do podsystemów, symulujące dwa rodzaje kanałów logicznych ACL (ang. Asynchronous Connection-Less) oraz SCO (ang. Synchronous Connection Oriented) zarówno dla urządzenia typu master jak i slave. Pierwszy z kanałów logicznych ACL używany jest w połączeniu z komutacją pakietów, kiedy dane są dostępne w nieregularnych odstępach czasu. W kanale logicznym typu ACL nie ma żadnych gwarancji, że ramka dotrze do celu. Ramki mogą zostać utracone i wymagać ponownej transmisji. Urządzenie slave może mieć tylko jeden kanał logiczny typu ACL z urządzeniem master. Drugi typ kanału logicznego to SCO i jest używany do transmisji w czasie rzeczywistym najczęściej transmisji głosu. Ramki transmitowane $\mathrm{w}$ kanale $\mathrm{SCO}$, nie mogą być ponownie przesyłane. Stosowana jest korekta błędów FEC, aby zapewnić niezawodność transmisji danych. Urządzenie typu slave może korzystać z maksymalnie trzech kanałów typu SCO przy transmisji $\mathrm{w}$ kierunku mastera. Zamodelowane sygnały pomiędzy dwoma urządzeniami master i slave umożliwiają symulację wymiany danych w sieci pikonet. Sygnał Tx_Raw_Bits1 symuluje działanie gdy urządzenie typu master generuje losowo dane informacyjne, wyznacza CRC oraz FEC, wysyła je zgodnie $\mathrm{z}$ formatem zdefiniowanym przez Bluetooth (podobnie w przypadku Tx_Raw_Bits2 dla urządzenia typu slave). Sygnał Signal_Tx1 symuluje działanie gdy urządzenie typu master pobiera Tx_Raw_Bits1 i moduluje zgodnie ze standardem Bluetooth. Signal_Tx1 jest transmitowany przez kanał (podobnie Signal_Tx2 dla urządzenia typu slave). Sygnał Signal_Rx1 symuluje działanie gdy pierwotny sygnał odebrany jest przy zakłóceniach addytywnych AWGN i interferencji przy transmisji danych dla standardu 802.11b. Signal_Rx1 jest podawany do urządzenia typu master w celu demodulacji i detekcji (podobnie, Signal_Rx2 jest dla urządzenia typu slave). Sygnał Tx_Info_Bits1 symuluje działanie gdy dane informacyjne generowane są przez urządzenie typu master z nagłówkiem pola danych CRC ale bez korekcji błędów FEC. Tx_Info_Bits1 jest używany do sprawdzania bitowej stopy błędów BER (ang. Bit Error Rate) w kanale logicznym typu SCO po stronie slave (podobnie, sygnał Tx_Info_Bits2 jest dla urządzenia typu master). Sygnał Diagnostics2 przesyła zbiór informacji o ramkach i pakietach dla kontroli BER w kanale logicznym ACL po stronie master (podobnie, sygnał Diagnostyka1 dotyczy urządzenia typu slave). Sygnał master_SCO symuluje działanie przesłania informacji BER w kanale logicznym $\mathrm{SCO}$ z urządzenia master (podobnie slave_SCO dla urządzenia typu slave). Sygnał master_ACL symuluje działanie przesłania informacji BER w kanale logicznym ACL z urządzenia master (podobnie slave_ACL dotyczy urządzenia typu slave). Sygnał Interference symuluje sygnał zakłóceń generowany z kanału 802.11b.

$\mathrm{W}$ celu przeprowadzenia symulacji transmisji głosu pomiędzy dwoma urządzeniami Bluetooth skonfigurowano model symulacyjny tak by przesyłane były pakiety dźwiękowe warstwy audio w kanale logicznym SCO. 
The use of bluetooth standard for communication between vehicles under traffic Wykorzystanie standardu bluetooth do komunikacji pomiędzy pojazdami ...

W trakcie symulacji pakiety audio przesyłane są w wyznaczonych szczelinach czasowych i nadawane parami w kierunku od urządzenia master do slave i w drugą stronę. Symulacji poddano trzy rodzaje pakietów audio:

- HV1 pakiet przenoszący dane audio zakodowane z użyciem FEC 1/3 zajmujący cały kanał fizyczny w pikosieci,

- HV2 pakiet przenoszący dane audio zakodowane z użyciem FEC 2/3 nadawany co 4 szczeliny czasowe,

- HV3 pakiet przenoszący dane audio niezakodowane nadawany co 6 szczelin czasowych.

W modelu symulacyjnym znajdują się bloki zliczające parametry transmisji w sieci Bluetooth (rys. 5). Wyznaczana jest tam przepustowość danych oraz bitowa stopa błędów BER zarówno dla kanału logicznego ACL oraz SCO w urządzeniach master oraz slave. Bloki wyznaczają trzy typy błędów BER:

- Raw BER - niespójności pomiędzy bitami w transmitowanym i odbieranym sygnale,

- Residual BER - prawdopodobieństwo, że dany bit będzie błędny i nie zostanie poprawnie wykryty,

- FER - wyznacza stosunek ilości uszkodzonych ramek danych do całkowitej liczby ramek spowodowany przez szum i zakłócenia oraz interferencje.

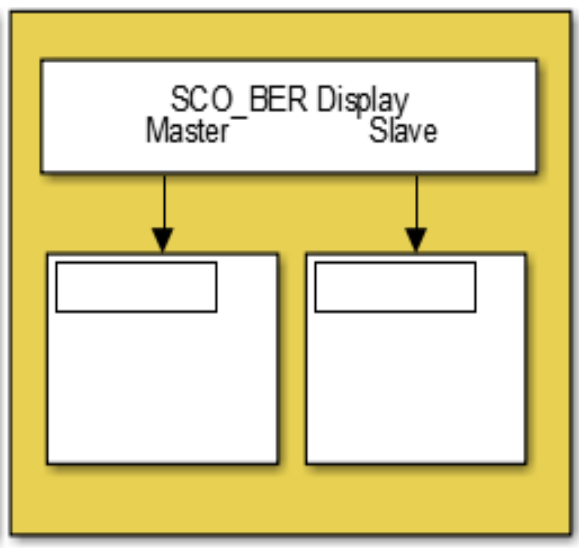

SCO BER Display

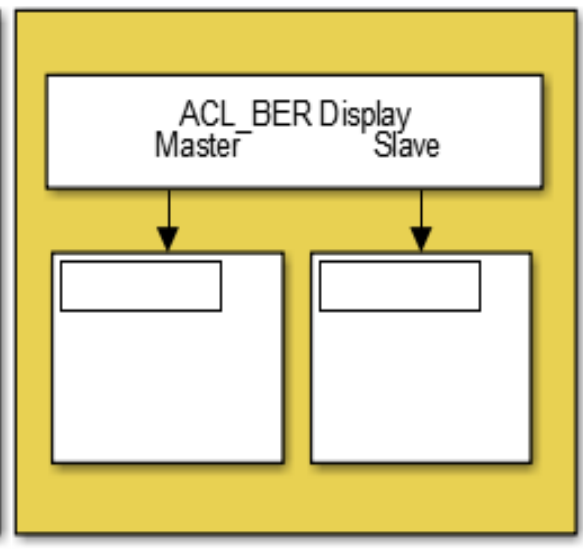

ACL BER Display

\section{Rys. 5 Bloki zliczajace parametry transmisji w sieci Bluetooth dla kanałów logicznych ACL oraz SCO}

Uruchomienie symulacji generuje schemat czasowy na rysunku 6 pokazujący, kiedy nadajnik Bluetooth działa. Wykres na rysunku 7 przedstawia widmo mocy każdego kanału, pokazujące bieżącą częstotliwość transmisji Bluetooth. Te dwie charakterystyki są rozpatrywane razem w zakresie spektrogramu na rysunku 8 tak by łatwo można było śledzić skok częstotliwości w funkcji czasu. 


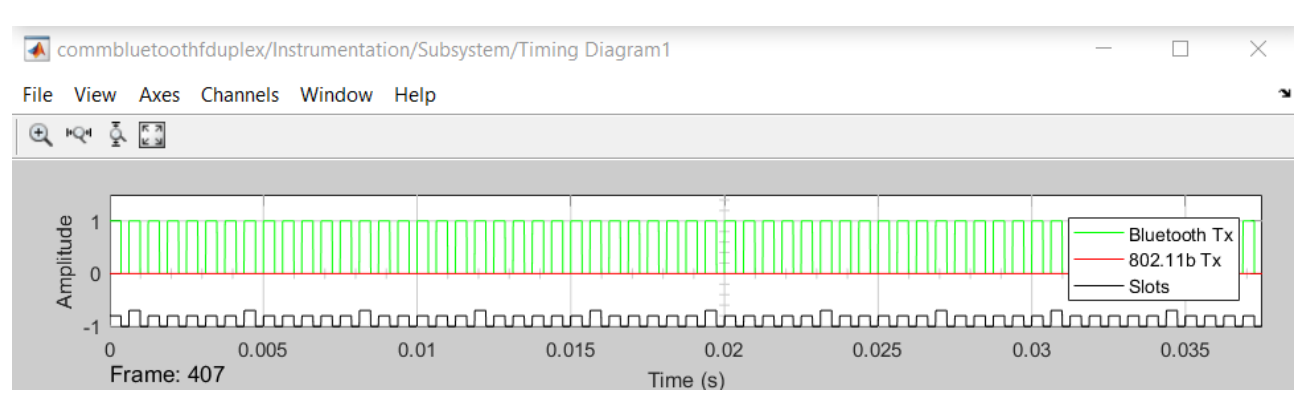

\section{Rys. 6 Schemat czasowy nadajnika Bluetooth}

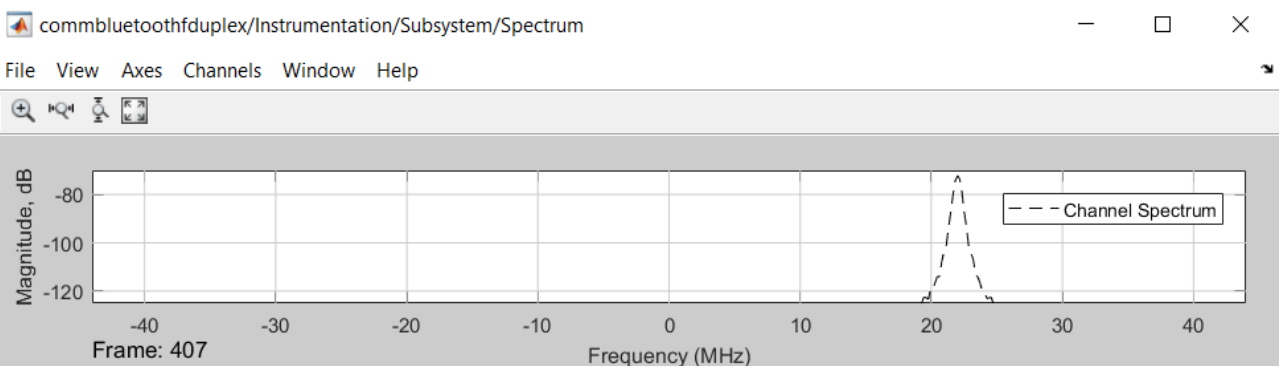

Rys. 7 Widmo mocy kanatu Bluetooth

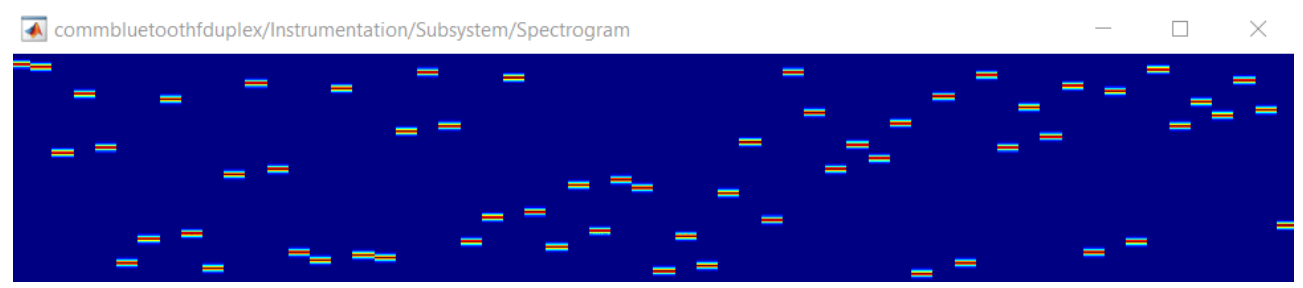

Rys. 8 Spektrogram transmisji Bluetooth

Kiedy nadajnik 802.11 b jest włączony, schemat czasowy nadajnika Bluetooth na rysunku 9 pokazuje nakładanie się transmisji Bluetooth i 802.11b. Spektrogram na rysunku 10 wyraźnie pokazuje interakcję transmisji z dwóch urządzeń w wyniku czego dochodzi do kolizji pakietów danych.

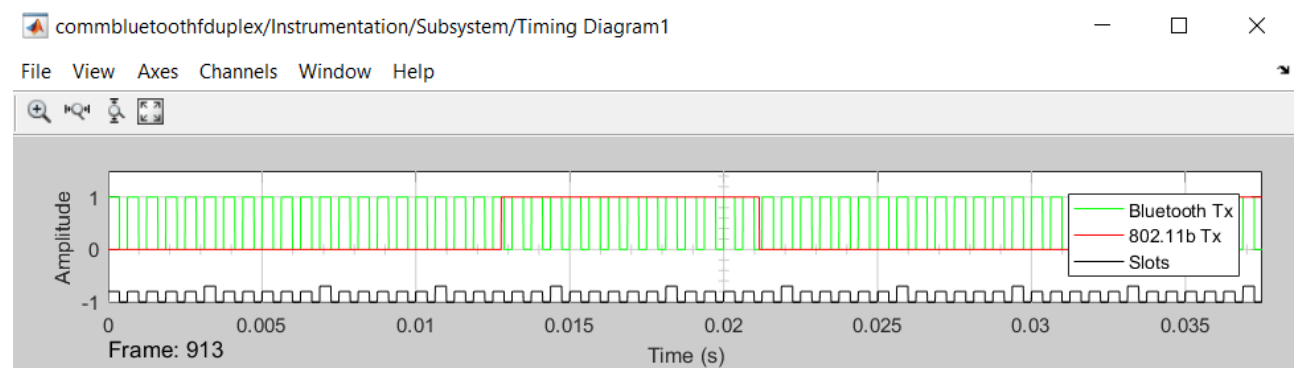

Rys. 9 Schemat czasowy nadajnika Bluetooth z właczona transmisja 802.11b 
The use of bluetooth standard for communication between vehicles under traffic Wykorzystanie standardu bluetooth do komunikacji pomiędzy pojazdami ...

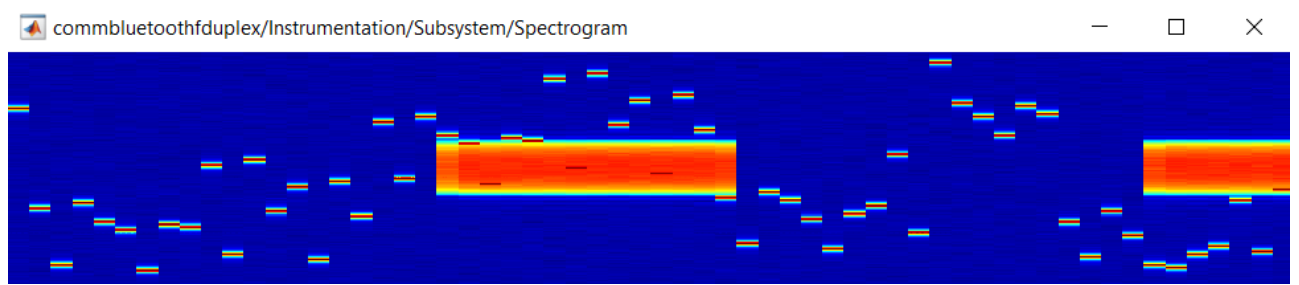

Rys. 10 Spektrogram transmisji Bluetooth $\mathrm{z}$ wtaczona transmisja $802.11 \mathrm{~b}$

Wyniki symulacji transmisji głosu pomiędzy dwoma odbiornikami Bluetooth do komunikacji pomiędzy pojazdami w warunkach ruchu przedstawiono w tabeli 1.

Tabela 1. Wyniki symulacji transmisji głosu w kanale logicznym SCO

\begin{tabular}{|l|l|l|c|c|c|c|c|c|}
\hline \multicolumn{1}{|c|}{$\begin{array}{c}\text { Typ } \\
\text { kanału }\end{array}$} & $\begin{array}{c}\text { Typ } \\
\text { pakietu }\end{array}$ & $\begin{array}{c}\text { Ilość } \\
\text { ramek }\end{array}$ & \multicolumn{2}{c|}{ Raw BER } & \multicolumn{2}{c|}{ Residual BER } & \multicolumn{2}{c|}{ FER } \\
\hline \multicolumn{2}{|c|}{} & Master & Slave & Master & Slave & Master & Slave \\
\hline $\begin{array}{l}\text { Bezpośrednie } \\
\text { połączenie }\end{array}$ & HV1 & 1000 & $1.859 \mathrm{e}+05$ & $1.863 \mathrm{e}+05$ & 0 & 0 & 0 & 0 \\
\hline $\begin{array}{l}\text { Bezpośrednie } \\
\text { połączenie }\end{array}$ & HV2 & 1000 & $8.857 \mathrm{e}+04$ & $8.894 \mathrm{e}+04$ & 0 & 0 & 0 & 0 \\
\hline $\begin{array}{l}\text { Bezpośrednie } \\
\text { połączenie }\end{array}$ & HV3 & 1000 & $6.222 \mathrm{e}+04$ & $6.222 \mathrm{e}+04$ & 0 & 0 & 0 & 0 \\
\hline AWGN & HV1 & 1000 & $1.859 \mathrm{e}+05$ & $1.863 \mathrm{e}+05$ & 0 & 0 & 0 & 0 \\
\hline AWGN & HV2 & 1000 & $9.370 \mathrm{e}+04$ & $9.370 \mathrm{e}+04$ & 0 & 0 & 0 & 0 \\
\hline AWGN & HV3 & 1000 & $6.185 \mathrm{e}+04$ & $6.185 \mathrm{e}+04$ & 0 & 0 & 0 & 0 \\
\hline $\begin{array}{l}\text { AWGN } \\
802.11 \mathrm{~b}\end{array}$ & HV1 & 1000 & $1.867 \mathrm{e}+05$ & $1.867 \mathrm{e}+05$ & 0.0031180 .001907 & 582 & 356 \\
\hline $\begin{array}{l}\text { AWGN } \\
802.11 \mathrm{~b}\end{array}$ & HV2 & 1000 & $9.333 \mathrm{e}+04$ & $9.333 \mathrm{e}+04$ & 0.0031390 .002325 & 293 & 217 \\
\hline $\begin{array}{l}\text { AWGN } \\
802.11 \mathrm{~b}\end{array}$ & HV3 & 1000 & $6.259 \mathrm{e}+04$ & $6.259 \mathrm{e}+04$ & 0.005928 & 0.003419 & 371 & 214 \\
\hline
\end{tabular}

\section{Podsumowanie i wnioski}

Przeprowadzona symulacja Bluetooth transmisji głosu w kanale logicznym SCO ukazuje iż wraz ze wzrostem czasu transmisji, co wiąże się z liczbą ramek nadawanych i odbieranych, wzrasta możliwość interferencji pomiędzy transmisją 802.11 b i Bluetooth. Dla kanału AWGN i 802.11 b gdy zachodzi interferencja oraz zakłócenia addytywne, największa ilość uszkodzonych ramek danych głosowych oraz niespójność pomiędzy bitami w transmitowanym i odbieranym sygnale, przy tym samym czasie transmisji, występuje w pakiecie HV1 przenoszącym dane audio zakodowane z użyciem FEC 1/3 zajmującym cały kanał fizyczny. 


\section{Literatura}

[1] http://www.bluetooth.com

[2] Marc Bechler, Jochen Schiller, Lars Wolf.: In-car communication using wireless technology, 8th World Congress on Intelligent Transport Systems, Sydney, Australia 2001-9-30 to 2001-10-4.

[3] F. Kargl, S. Ribhegge: Bluetooth-based ad-hoc networks for voice transmission, System Sciences, 2003. Proceedings of the 36th Annual Hawaii International Conference on 6-9 Jan. 2003

[4] https://www.mathworks.com/help/comm/examples/bluetooth-full-duplexvoice-and-data-transmission.html?requestedDomain=true

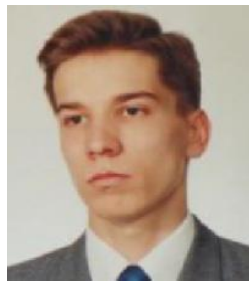

Dr inz. Zbigniew Kasprzyk, adiunkt na Wydziale Transportu, Politechniki Warszawskiej. Obszary badawcze to: modelowanie systemów poboru opłat, modelowanie funkcji sprzętu telematyki transportu, analiza systemów operacyjnych, analiza niezawodności sieci teleinformatycznych. Autor kilkudziesięciu artykułów naukowo-technicznych (udziat 50\%).

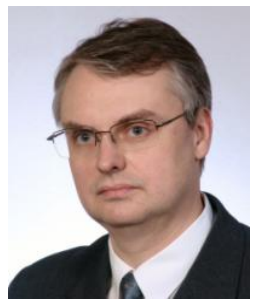

Dr inj.Mariusz Rychlicki, adiunkt na Wydziale Transportu, Politechniki Warszawskiej. Obszary badawcze to: modelowanie systemów telematyki, analiza monitorowania $i$ systemów lokalizacyjnych, analiza niezawodności sieci transmisji danych. Autor kilkudziesięciu artykułów naukowo-technicznych (udziat 50\%). 